Int. J. Electrochem. Sci., 14 (2019) $2526-2538$

International Journal of

ELECTROCHEMICAL

SCIENCE

www.electrochemsci.org

\title{
Corrosion Inhibition Potentials of 4-(4-bromophenyl) Thiosemicarbazide for Mild Steel In 1.0 M HCl as Theoretical and Experimental
}

\author{
Abdelhakim Alrjaibi ${ }^{1}$,Emel Bayol ${ }^{2}$, Fatma Kandemirli, ${ }^{3, *}$ \\ ${ }^{1}$ Department of Materials Science \& Engineering, Faculty of Engineering and Architecture, \\ Kastamonu University, 37200 Kastamonu, Turkey \\ ${ }^{2}$ Department of Chemistry, Faculty of Art and Science, Niğde Ömer Halisdemir University, 51240 \\ Niğde, Turkey \\ ${ }^{3}$ Department of Biomedical Engineering, Faculty of Engineering and Architecture, Kastamonu \\ University, 37200 Kastamonu, Turkey \\ *E-mail: hakimrj2011@yahoo.com
}

doi: $10.20964 / 2019.03 .44$

Received: 26 June 2018 / Accepted: 8 January 2019 / Published: 7 February 2019

This examination researched the impact of changing measures of 4-(4-bromophenyl) Thiosemicarbazide (4-BrPhTSC) by assessing air conditioning impedance and AC and flow potentiometry in a $1 \mathrm{M} \mathrm{HCl}$ arrangement at $20^{\circ} \mathrm{C}$. In an unlimited arrangement, when the $\mathrm{E}_{\text {corr }}$ value is - $0.518 \mathrm{~V}$, the concentration of the inhibitor solution changes and the grouping of the inhibitor changes. The present's thickness of the anodic and cathodic districts is bring down contrasted with that of the $1.0 \mathrm{M} \mathrm{HCl}$ arrangement, with an $\mathrm{I}_{\text {corr }}$ estimation of $158.78 \mu \mathrm{A} \cdot \mathrm{cm}^{-2}$ in the uninhibited arrangement and $8.10 \mu \mathrm{A} \cdot \mathrm{cm}^{-2}$ at the $1 \times 10^{-2} \mathrm{M}$ concentration of 4-BrPhTSC. It very well may be seen that as the grouping of the inhibitor builds, the consumption current thickness value diminishes, and the restraint productivity value likewise increments. The percent restraint proficiency extended from $71 \%$ to $95 \%$. For the uninhibited and most astounding grouping of 4-BrPhTSC arrangement, the estimations of Rpblank and Rpinh were 235 and 2006 $\Omega . \mathrm{cm}^{-2}$, separately, CPE blank and CPE $E_{\text {inh }}$ were 348 and $36 \mu \mathrm{F} . \mathrm{cm}^{-2}$, individually, $\mathrm{n}_{\text {blank }}$ and $\mathrm{n}_{\text {inh }}$ were 0.94 and 0.84. As the Rp esteem builds, the CPE esteem and $n$ diminish as the inhibitor focus increments, potentially because of abatement in neighborhood dielectric steady or an expanded thickness at the metal/arrangement interface. The adsorption of the inhibitor on the surface of the low carbon steel fits in with the Langmuir show. Also, the adsorption harmony steady and the adsorption free vitality were evaluated. For the subsidiaries of 4-BrPhTSC, the estimation of $\Delta \mathrm{G}^{\mathrm{o}}$ ads and is $-36.00 \mathrm{~kJ} \mathrm{~mol}^{-1}$, demonstrating that the adsorption of these inhibitors includes two sorts of communications: physical adsorption and chemisorption. The thickness utilitarian hypothesis (DFT) of the B3LYP work with the 6-311G (d,p) premise set was performed on 4-BrPhTSC as appeared in Table 1, Table 2.

Keywords: Corrosion, inhibition, low carbon steel, Thiosemicarbazide, quantum chemistry research. 


\section{FULL TEXT}

(C) 2019 The Authors. Published by ESG (www.electrochemsci.org). This article is an open access article distributed under the terms and conditions of the Creative Commons Attribution license (http://creativecommons.org/licenses/by/4.0/). 